\title{
九州モノづくり技術の伝承と創成に関する研究分科会 九州支部活性化のための仕掛け* \\ A Scheme to Activate Kyushu Branch of JSPE
}

\section{安井平司 ${ }^{* *}$ \\ Heiji YASUI}

Key words inheritance and creation, manufacturing techniques, Kyushu area

\section{1. は じめに}

本年から始まった, 団塊の世代の引退による「2007 年 問題」の主要なものの一つは, 我が国に扔けるモノづくり 技術の伝承である。企業の年齢層割合からみて，もとも と，高度な技術者・技能者の後継者不足が指摘されてい た，それに加えて，近年におけるバブル崩壊後の最終的な リストラにより，後継者の一部も減少した，景気が大きく 改善し, 生産量が増加する一方, 製作される製品の品位向 上も著しい，競争に打ち勝つため，高度な生産技術を維持 し，新たに創成することが必要で，不足を補完するための 問題が益々大きく浮上している。このため，近年，日本の 各地域に㧈けるモノづくりを支援する国家戦略 ${ }^{11}$ が策定さ れている，企業においても，問題解消に大きな努力が傾注 されている

精密工学会は，世界最大の精密生産技術に関係する技術 者・研究者の集団で，「モノづくり技術の“KEY 学会”」で ある. 九州地域に打いても, この問題に, 学会が寄与し得 るところは多々あると考えられる。しかしながら，九州支 部では過去 15 年間に正会員数が 100 名近く減少している. この間, 業績改善のための企業改革において学会の必要性 が見直された。それに相まって，2001 年以降に実施され た，IT 国家戦略 ${ }^{2)}$ による超高速ネットワークのインフラ 整備があり，モノづくり技術に関する最新情報が瞬時に, かつ，無料でインターネットにより入手できるようになっ たことも影響したかと思われる。

このような事態に, 九州支部では危機感を感じ, 支部活 性化の一環として, 2006 年 2 月に本研究分科会を発足さ

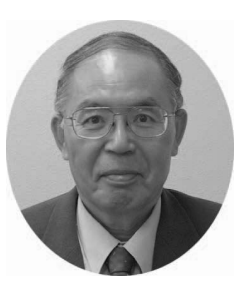

*原稿受付 平成 19 年 7 月 26 日

*正会員 熊本大学大学院自然科学研究科 (熊 本県熊本市黒髪 2-39-1)

安井平司

1973 年大阪大学大学院博士課程修了. 工学博 士. 1974 年熊本大学助教授, 1985 年同教授. 研究分野は精密機械加工, 精密機器製作. 現 在, 切削加工, 研削加工, ポリシング加工を用 いた超精密機械加工に関する研究に注力.
せた。 モノづくり技術の研究に加えて教育も含めた分科会 である，九州地域の枠で一体的に統括しながらも，九州各 県の事情に即した形態で分散して実施されている点に特徵 がある。

本稿では，まず初めに本分科会設置の背景を述べ，その 上で，これまでの活動状況について紹介する。

\section{2. 九州支部会員数の変遷}

精密工学会九州支部は 1961 年に創設されて以来，今期 で 47 年目を迎える。過去 47 年間の会員数の変遷を図 1 に示す，多少の変動はあるが，バブル経済が崩壊する 1991 年までの間，正会員数は右肩上がりに増加し，約 350 名に達した。バブル崩壊後数年で, 正会員数は 50 名程度 減少した。しかし，その後，2003 年頃までは，概ね 300 名を維持した，2002 年には, 熊本で精密工学会秋季大会 が盛大に開催され，減少に歯止めがかかった感があった。 しかし, 2004 年以降, 正会員数が再び減少するという事 態を迎えた。この減少は，主に，企業正会員によるところ が大きかった。図 1 では分かり難いが, 賛助会員数は 1998 年以降, 長期低落状態にある. ただ, 救いは学生会 員の増加であるが, 支部正会員への増加に直接的にはつな がらず，長い目でみる必要があった。

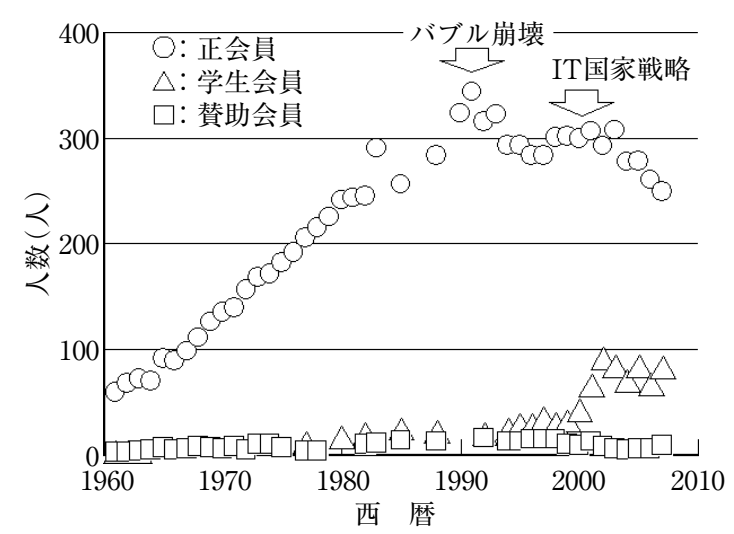

図 1 精密工学会九州支部·会員数の変遷 


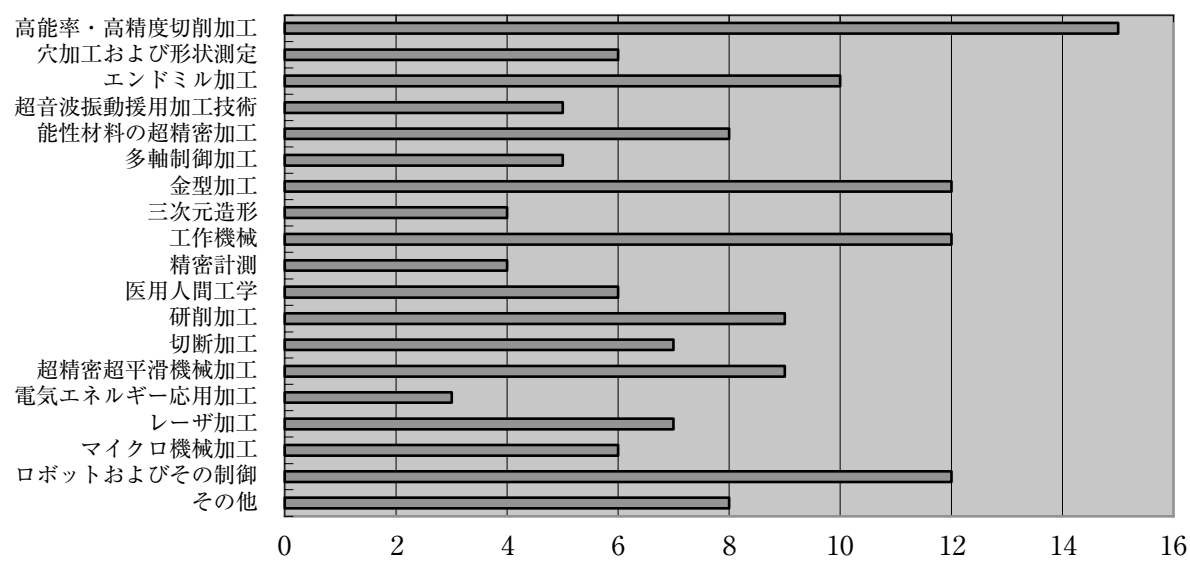

図 2 地域企業に対するアンケート調査の結果（質問：技術講習会を行うとして，どのようなテ ーマでの講習会を希望されますか？）

各企業において，現在のような好業績にするために，徹 底した改革が行われ，その中で，学会の必要性が見直され た。そそれに相まって, IT 国家戦略 ${ }^{2}$ による超高速ネット ワークのインフラ整備で，インターネットにより最新技術 情報が瞬時に，かつ，無料で入手できるようになったこと も，企業会員の減少に影響したかと思われる。

九州支部では，このような状況に危機感を感じ，2005 年度の始めから， 企業正会員数の増加を行うための議論を 重ねた。そして，企業が必要としているモノづくりに関わ る情報の発信・受信を頻繁にすることが重要と考え，従来 からの施策を，一度見直し，新たなものを考えることとし た，方法は，大企業ももちろんであるが，我が国の川中産 業を支えている中小企業に対して重点を置き，会員増加を 計ろうとするものであった．新しい施策は，次のようなも のである

1）支部組織の改編

2）九州モノづくり技術の伝承と創成に関する研究分科 会の設置

3）支部学術講演会の地区輪番制の実施

4）産官学技術交流七ミナーの実施

5）ミ二講習会の実施

6）その他（ホームページの充実）

\section{3. 地域企業に対するアンケート調査の結果}

会員増加を考えるに先だって，地域企業が必要としてい る情報を把握する必要があると判断し，仙波副支部長を中 心に，2005 年の 6 月末から 8 月末までの 2 ケ月間，地域企 業 490 社に対して,アンケート調査を実施した。内容は, 技術講演会, 研究分科会, 共同研究ならびにプロジェクト 研究等の項目についてである。例えば，技術講習会のアン ケート内容は,

・過去に技術講習会に参加した経験

・将来に技術講習会に参加する意向

·技術講習会の内容

等である。
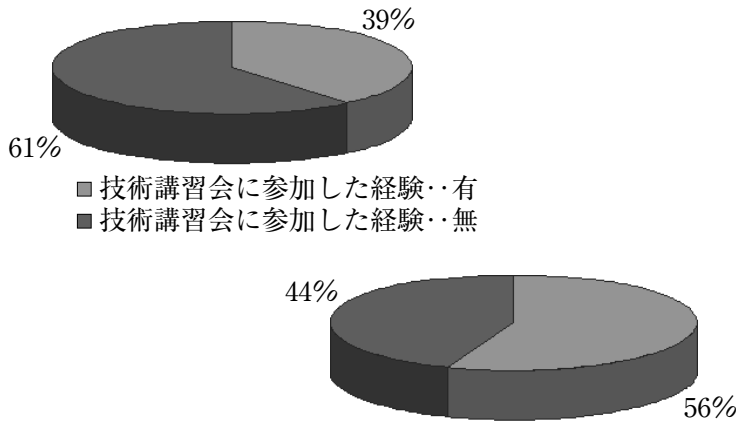

口技術講習会に参加する意向・・有

口技術講習会に参加する意向・無

図 3 地域企業に対するアンケート調査の結果（質問：過去に技術 講習会に参加された経験を㧍もちですか？ 将来に技術講習 会に参加される意向を扔もちですか?）

アンケートの回収率は 490 社の 18.5\%（84 社）であっ た。回答結果は，技術講習会を例に取ると，図 2 に示す ように，地域企業は，九州支部の公的機関でシーズ的研究 を行っている各項目に，関心をもっていることがわかっ た。また，図３に示すように，過去に開催された技術講 習会に参加経験のある企業は 84 社の 39\%（33 社）である が，将来，技術講習会に参加意向をもつ企業は 56\%（47 社）に上ることが見いだせた.

九州支部のホームページ3) に掲載しているように，モノ づくり技術に関する研究分科会，共同研究ならびにプロジ エクト研究に関しても，50 社前後の会社は関心をもって いることが判明した。アンケート調査を実施した 2005 年 度当初の賛助会員数は 6 社にまで減っていたが，50 社前 後の会社がモノづくり技術に関心をもっていることは，賛 助会員数の増加方策を策定する上で大きな自信につながっ た。

\section{4. 支部組織の改編}

九州支部が，企業ニーズに迅速に対応し，企業との情報 を密にするためには，支部の組織・運営方法を大きく改革 
する必要があると考えた。そして，地域企業が必要として いる情報を迅速に発信する手段として，次のようなことを 2005 年度前半に企画した。（1）各年度ごとに各県を回っ て行っていた技術講習会では情報量に限りがあると判断 し，年に 2 度，九州地区全体の産官学技術交流セミナーの 実施，（2）支部活性化のための新たな研究分科会の発足, （3）支部ホームページの充実等である。なお，従来行って きた技術講習会は規模を縮小した「ミ二講習会」として, 継続実施することにした。この中で，ホームページの充実 は，既設の広報部会により 2005 年度中に作業を終了した。

一方，産官学技術交流セミナーや研究分科会を発足さ せ，それらを企画・運営するには，既存の運営体制では不 十分で，新たな企画立案を行う組織を支部組織内に作る必 要が出てきた。このようなことから，支部組織を図 $4^{4)}$ の ように改編することを考え，2005 年 10 月開催の鹿児島で の支部総会に提案し，承認を得た。近未来を見据えた企画 を行う戦略会議，産学官技術交流セミナーのための委員会 ならびに研究分科会のための委員会等を新設した。また， 支部運営を迅速化するために，支部商議員の人数を従来の 25 名から 35 名に増加した。

\section{5. 産官学技術交流セミナー}

第 1 回目産官学技術交流セミナーを, 支部組織改編承認 の 2 ケ月後の 2006 年 1 月に開催した。テーマは, 図 2 の アンケート調査結果を踏まえ,「高速・高精度加工とそれ を支える基盤技術の最新動向」である，従来の技術講習会 と異なり，地域企業間で情報交換をするためのパネル展示 コーナをセミナー会場に設置した。また，名刺交換のため の懇親会を行い，産学官での交流を深めるための場を設け た．盛況で参加者にも好評であった，その後，当初計画の 通り,さらに2 回のセミナーを実施している。テーマは, 「然料電池の開発動向と加工技術に求められるもの」，「プ ラスティック射出成形技術と金型加工技術の動向」であ る. 計 3 回のセミナーへの参加人数は延べ 162 名，そのj ち企業からの参加人数は 87 名であった。今後とも, 地域 企業のニーズと最先端シーズを組み合わせたセミナーを継 続して開催し，地域企業のニーズを拝聴する必要があると 感じている

\section{6. 分科会活動と活動状況の紹介}

九州支部で研究分科会を設置するので，そのテーマが重 要である。折しも，2007 年問題があり，「モノづくり技術 の伝承」であれば，支部として，かねて取り上げるべき問 題としていた各県共通のテーマであり，適当であると考え られた。しかし，伝承のみでは，発展性がなく，また，モ ノづくりに関するシーズをもっている大学・高専・公設機 関等の公的機関とニーズがある企業との連携が容易に進ま ないとの観点から，「技術の創成」も重要であるとの結果 に至った，創成の立場であると，公的機関で行っているシ ーズ研究の教育を行う，先端技術教育も実施し得るとの考

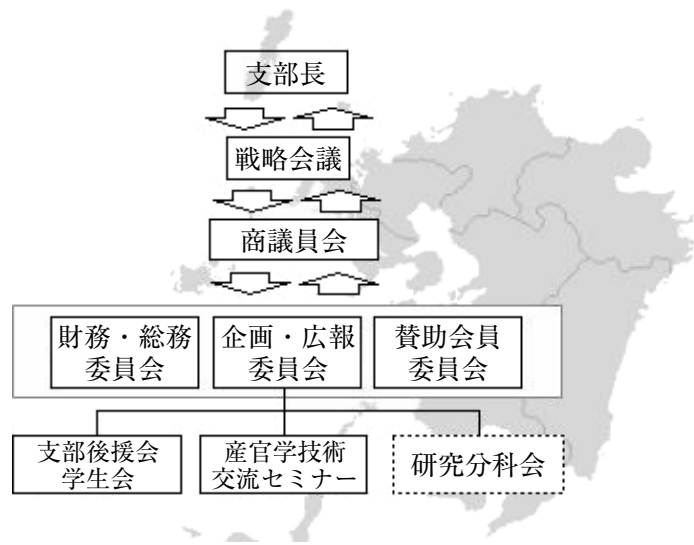

図 4 支部組織の改編

えである

以上のようなことで，実際に，「九州モノづくり技術の 伝承と創成に関する研究分科会」の運営組織を検討した. 「伝承」は，教育が重要であり，また，実習が必要である。 つどつど，遠くから集まって，研修会などを開催すること は難しい，そこで，まずは，九州の各県単位で，その県の 事情を考えて，実習を含んだ研修会等の教育を行うことと した。一方，創成の方は，九州各県の大学 - 高専 - 公設機 関にあるシーズに基づいた講義，実習，演習等による教育 を行う。その中で, 企業の関心のあるものについては, 共 同研究等へと進める。「技術の創成」の実施対策も, 各県 の大学・高専・公設機関の方々をチーフにおき，それぞれ で内容を決めて研修会等を行う。企業は県境の仕切りを気 にせず，自由に参加できる。

このような企画案ができたのが，2005 年 11 月で，その 後, 精密工学会に申請し, 理事会で認められたのが 2006 年 1 月末であった。そして，2006 年 2 月に分科会は発足 した。現時点での分科会員数は大学 - 高専 - 公設研究機関 からの 31 名と企業会員 27 名の合計 58 名に達している. 表 1 に，平成 18 年度に実施した分科会活動の一覧を示 す。分科会活動に参加があった企業受講生等の数は延べ 521 名に達する。

講義，実習，演習を担当する先生方に負担がかかること は事実であるが，先行して実施している産官学技術交流セ ミナーに比べると，はるかに多くの企業参加者から生の声 を拝聴できる特徴がある。また，分科会活動がきっかけに なって，大学・公設研究機関と参加企業との間で共同研究 が開始されたといった，喜ばしいニュースも伝わってい る。このような進展を受け，2007 年 8 月に開催する総会 時に大学・高専・公設機関のシーズ発表会を実施すること になった。表 2 に示すのは，シーズ発表会での講演題目 である。講師の先生方には，シーズ研究発表の他に平成 18 年度に実施された講義と演習についての紹介もいたた く予定で，分科会活動のレベルアップにつなげることを計 画している。 
表 1 平成 18 年度に実施した分科会活動の一覧

\begin{tabular}{|c|c|c|c|c|c|}
\hline 地区 & 担当者 & 講義あるいは演習の名称 & $\begin{array}{l}\text { 講義 } \\
\text { 時間 }\end{array}$ & $\begin{array}{l}\text { 演習 } \\
\text { 時間 }\end{array}$ & 参加者数 \\
\hline \multirow{4}{*}{ 福岡 } & \multirow{3}{*}{ 仙波卓弥 } & 打製石器から半導体に至るまでのモノづくりの歴史 & 1.5 & & 20 \\
\hline & & 最先端のマイクロ工具 & 1.5 & & 23 \\
\hline & & PCD 工具を作った超硬合金に対する高速微細加工 & & 3.0 & 23 \\
\hline & 鈴木 裕 & 3 次元 CAD/CAM による高速直彫り加工体験 & & 6.0 & 15 \\
\hline \multirow{3}{*}{ 大分 } & \multirow{3}{*}{ 木下和久 } & 幾何公差に関する試験法と精密加工における $\mathrm{AE}$ 信号解析 & 1.5 & & 15 \\
\hline & & ファインセラミックスの精密加工と AE 計測法 & 1.5 & & 20 \\
\hline & & 素形材産業と各種鋳造技術 & 1.5 & & 60 \\
\hline \multirow{4}{*}{ 長崎 } & 中島昭二 & 3 次元計測器の取扱とフライス加工の精度計測 & & 4.0 & 30 \\
\hline & \multirow{3}{*}{ 川下智幸 } & 3 次元 CAD 実用講座 & & 6.0 & 77 \\
\hline & & サーボ制御技術演習 & & 6.0 & 45 \\
\hline & & $\mathrm{CAD} \cdot \mathrm{CAM}$ 実践実習 & & 6.0 & 33 \\
\hline \multirow{4}{*}{ 熊本 } & \multirow{3}{*}{ 安井平司 } & 新概念ナノ超精密機械加工セミナー & 1.5 & & 20 \\
\hline & & 超精密切削加工技術 & & 1.5 & 10 \\
\hline & & ナノメータ超平滑研削加工技術 & & 1.5 & 10 \\
\hline & 睦 & 先端のラッピング・ポリシング加工 & 1.5 & & 23 \\
\hline \multirow{4}{*}{ 鹿児島 } & \multirow{4}{*}{ 河野良弘 } & 機械加工技術 & & 8.0 & 19 \\
\hline & & アクチユエータ制御技術 & 4.0 & & 15 \\
\hline & & ロボット工学 & 4.0 & & 25 \\
\hline & & 計測技術 & 4.0 & & 38 \\
\hline
\end{tabular}

表 2 平成 19 年 8 月の総会時に実施する研究シーズ発表会での講演題目

\begin{tabular}{|c|c|c|c|}
\hline 地区 & 講師氏名 & 勤務先 & 講演題目 \\
\hline \multirow{4}{*}{ 福岡 } & 鈴木 裕 & 九州工業大学 & ヘール加工に基づく精密加工技術 \\
\hline & 水垣善夫 & 九州工業大学 & 逆運動学に基づく多軸加工用 CAM 開発の一考察 \\
\hline & 仙波卓弥 & 福岡工業大学 & 超精密・微細加工用工具についての紹介 \\
\hline & 大西 修 & 九州大学大学院 & 超音波振動マイクロ穴加工 \\
\hline \multirow{2}{*}{ 大分 } & 木下和久 & 大分大学 & AE 信号の伝播特性と精密加工における活用 \\
\hline & 大塚裕俊 & 大分県産業科学技術センター & 高硬度材の小径エンドミル加工に関する研究 \\
\hline 佐賀 & & 佐賀大学 & セラミック球の超精密高能率研削について \\
\hline \multirow{2}{*}{ 長崎 } & 扇谷保彦 & 長崎大学 & 創成点固定による小径エンドミル加工の高精度化 \\
\hline & 川下智幸 & 佐世保工業高等専門学校 & サーボ制御と画像処理による研削砥石の 3 次元切れ刃計測システム \\
\hline \multirow{2}{*}{ 熊本 } & & 熊本大学 & 熱工学とマイクロ加工技術の接点 \\
\hline & 坂本重彦 & 熊本大学 & CFRP の高精度穴あけ加工 \\
\hline 宮崎 & 外山真也 & 宮崎県工業技術センター & C\# 言語による二次元 CAD/CAM ソフトの開発 \\
\hline \multirow{2}{*}{ 鹿児島 } & 近藤英二 & 鹿児島大学 & エンドミル加工におけるびびり振動の検出と振動抑制制御 \\
\hline & 河野良弘 & 鹿児島工業高等専門学校 & 小径エンドミルの挙動監視技術 \\
\hline
\end{tabular}

\section{7.おわりに}

はじめに述べたとおり，本研究分科会は，バブル崩壊以 降の景気低迷の中で，学会が関係し得る多くの問題がある にもかかわらず，過去 15 年間に九州支部正会員数が 100 名近く減少するといった深刻な事態に対応するために設置 された。このため，本稿の内容に支部紹介のような内容が 多く含まれたが，それらは，本分科会活動に非常に関連す ることである。その背景を受け，分科会の活動を大いに発 展させるとともに，支部活動の活性化を計りたいと考えて いる.

本分科会の発足効果として，（1）九州における企業のモ ノづくり技術の伝承と創成に，幾分かでも寄与できている
ことや，(2）産学共同研究が開始されたことがある。さら に，支部活性化支援について，（3）2004 年度に，6社まで 減少した賛助会員数が現時点で 9 社にまで回復したことが ある。これらは，本研究分科会活動を実施する上で，大き なはげみになっており，分科会の進展に尽力したく考えて いる.

\section{参 考 文 献}

1) http://www8.cao.go.jp/cstp/kihonkeikaku/kihon3.html

2) http://www.kantei.go.jp/jp/singi/it2/

3) http://www.mech.kumamoto-u.ac.jp/jspe/

4）仙波卓弥：九州支部の近況，精密工学会誌，72,1 (2006) 64 